\title{
The Identikit of Patient at Risk for Severe COVID-19 and Death: The Dysregulation of Renin-Angiotensin System as the Common Theme
}

\author{
Riccardo Sarzani ${ }^{1,2, *(D)}$, Massimiliano Allevi ${ }^{1,2}$, Federico Giulietti ${ }^{1,2}$, Chiara Di Pentima ${ }^{1,2}$, Serena Re ${ }^{1,2}$, \\ Piero Giordano ${ }^{1}$ and Francesco Spannella ${ }^{1,2} \mathbb{D}$ \\ 1 Internal Medicine and Geriatrics, IRCCS INRCA, Via della Montagnola 81, 60127 Ancona, Italy; \\ m.allevi@inrca.it (M.A.); f.giulietti@inrca.it (F.G.); c.dipentima@inrca.it (C.D.P.); s.re@inrca.it (S.R.); \\ p.giordano@inrca.it (P.G.); f.spannella@univpm.it (F.S.) \\ 2 Department of Clinical and Molecular Sciences, University "Politecnica delle Marche", Via Tronto 10/a, \\ 60126 Ancona, Italy \\ * Correspondence: r.sarzani@univpm.it; Tel.: +39-071-596-4231
}

check for

updates

Citation: Sarzani, R.; Allevi, M.; Giulietti, F.; Di Pentima, C.; Re, S.; Giordano, P.; Spannella, F. The Identikit of Patient at Risk for Severe COVID-19 and Death: The

Dysregulation of Renin-Angiotensin System as the Common Theme. J. Clin. Med. 2021, 10, 5883. https:// doi.org/10.3390/jcm10245883

Academic Editor: Patrick De Boever

Received: 19 November 2021

Accepted: 13 December 2021

Published: 15 December 2021

Publisher's Note: MDPI stays neutral with regard to jurisdictional claims in published maps and institutional affiliations.

Copyright: (C) 2021 by the authors. Licensee MDPI, Basel, Switzerland. This article is an open access article distributed under the terms and conditions of the Creative Commons Attribution (CC BY) license (https:/ / creativecommons.org/licenses/by/ $4.0 /)$.

\begin{abstract}
Since the first months of the coronavirus disease 2019 (COVID-19) pandemic, several specific physiologic traits, such as male sex and older age, or health conditions, such as overweight/obesity, arterial hypertension, metabolic syndrome, and type 2 diabetes mellitus, have been found to be highly prevalent and associated with increased risk of adverse outcomes in hospitalized patients. All these cardiovascular morbidities are widespread in the population and often coexist, thus identifying a common patient phenotype, characterized by a hyper-activation of the "classic" renin-angiotensin system (RAS) and mediated by the binding of angiotensin II (Ang II) to the type 1-receptor. At the same time, the RAS imbalance was proved to be crucial in the genesis of lung injury after severe acute respiratory syndrome coronavirus 2 (SARS-CoV-2) infection, where angiotensinconverting-enzyme-2 (ACE2) is not only the receptor for SARS-CoV-2, but its down-regulation through internalization and shedding, caused by the virus binding, leads to a further dysregulation of RAS by reducing angiotensin 1-7 (Ang 1-7) production. This focused narrative review will discuss the main available evidence on the role played by cardiovascular and metabolic conditions in severe COVID-19, providing a possible pathophysiological link based on the disequilibrium between the two opposite arms of RAS.
\end{abstract}

Keywords: COVID-19; SARS-CoV-2; cardiovascular disease; renin-angiotensin system; older age; overweight; obesity; hypertension; metabolic syndrome; diabetes mellitus

\section{Introduction}

The coronavirus disease 2019 (COVID-19), caused by the severe acute respiratory syndrome coronavirus 2 (SARS-CoV-2), was first reported in December 2019 in Wuhan, China [1]. Since then, COVID-19 has exponentially spread all around the world, making the World Health Organization (WHO) declaring it a pandemic on March 11, 2020. Until now, there have been millions of deaths worldwide. Since the first months of the pandemic, several specific physiologic traits, such as male sex and older age, or health conditions, such as overweight/obesity, arterial hypertension, metabolic syndrome, and type 2 diabetes mellitus, have been found to be highly prevalent and associated with increased risk of adverse outcomes in hospitalized COVID-19 patients [2]. The first report on hospitalized COVID-19 patients in Wuhan found that hypertension (31.2\%), diabetes mellitus (10.1\%), cardiovascular disease $(14.5 \%)$, and malignancy $(17.2 \%)$ were the most common related health conditions [3]. In March 2020, the American College of Cardiology (ACC) issued a clinical bulletin confirming that patients suffering from hypertension, diabetes, and cardiovascular disease had higher case fatality rates than the average population. In a large case series of sequentially hospitalized COVID-19 patients in the New York City area between 
March 2020 and April 2020, the most common comorbidities were hypertension (56.6\%), obesity (41.7\%), and diabetes (33.8\%) [4]. Furthermore, meta-analytic data confirmed significant positive correlations between COVID-19 severity and hypertension, diabetes, and coronary heart disease [5]. Case-control studies have reported that obesity, together with diabetes and hypertension, were the strongest predictors for COVID-19, being associated not only with illness severity but also with higher risk of acquiring the infection [6].

Why do these conditions characterize the most severe COVID-19? It is very likely that the "classic" renin-angiotensin-system (RAS) and angiotensin-converting-enzyme (ACE) 2 play a key role in this scenario. ACE2 is the cellular receptor for SARS-CoV2 [7], but its functional down-regulation, through internalization and shedding caused by the virus binding, can lead to an imbalance between the two arms of RAS, leading to tissue damage after SARS-CoV-2 infection by unopposed angiotensin II (Ang II)-AT1 receptor (AT1R) activity [8]. A very large quantity of experimental evidence confirmed by high-quality clinical research performed before the SARS-CoV-2 pandemic demonstrated that RAS dysregulation, resulting from the disequilibrium between these two opposite arms, driven by ACE and ACE2, may be a crucial factor in the genesis of lung injury in SARS-CoV-2 infection [9]. In the following focused narrative review, we will discuss the role played by cardiovascular and metabolic conditions in determining the risk for severe COVID-19, proposing a conceivable pathophysiological link underpinning all, based on the dysregulation of RAS.

\section{Disequilibrium between ACE and ACE2 Activity as a Potential Causal Mechanism for Severe COVID-19}

The RAS plays a fundamental role in the regulation of fluid volume and blood pressure, but it also exerts a large spectrum of effects on several tissues, especially those that are microvasculature-rich, such as the lungs. Renin, a protease produced by renal juxtaglomerular cells in its active form, cleaves angiotensinogen, released mainly by the liver, to form Ang I. A pathophysiological mechanism underlying the cardio-metabolic conditions associated with a greater risk of morbidity and mortality in COVID-19 is the imbalance between ACE and its homologous ACE2, with a decreased activity of the latter and impairment of its protective effects. Similarly to ACE, ACE2 is a ubiquitous enzyme, particularly expressed in the lungs but also present on the enterocytes of the small intestine and on the endothelial cells of several organs and systems, such as the brain, cardiovascular system, and kidney [10,11]. ACE and ACE2 are key enzymes in the metabolism of Ang I: ACE, expressed widespread by endothelial cells, catalyzes the conversion of Ang I to the octapeptide Ang II [12], which exerts its effects via Ang II type 1 and type 2 receptors (AT1R and AT2R, respectively). In particular, binding of Ang II to AT1R is the one most commonly expressed in normal adult tissues, stimulating vasoconstriction, sodium reabsorption, and blood pressure increase, promoting vascular damage, inflammation, and fibrosis [13]. On the opposite side, ACE2 is a type I transmembrane metallocarboxypeptidase that cleaves Ang I into a nonapeptide [Ang (1-9)] that binds AT2R and Ang II into a heptapeptide [Ang (1-7)] that binds its specific receptor, initially identified as an "oncogene" (Mas receptor, MasR) [14]. The two main effects of ACE2 are thereby the degradation of Ang II, the principal effector of the "classic" RAS arm through AT1R, and the production of Ang (1-7), which exerts opposite effects by inducing vasodilatation as well as anti-inflammatory and anti-fibrotic pathways through binding to the MasR [15]. ACE2 also interacts with another sub-branch of RAS based on Ang peptides in which the aminoterminal aspartate is replaced by alanine (Alatensins), leading to the production of Ala-Ang (1-7) (Alamandine) that has been found to bind Mas-related $\mathrm{G}$ protein-coupled receptor $\mathrm{D}(\mathrm{MrgD})$ and may also protect against lung injury and fibrosis, improving vascular/endothelial dysfunction [11]. The ACE2/Ang (1-7)/MasR axis has been found to attenuate inflammation and fibrosis in experimental models to prevent heart failure and coronary heart disease [16], as well as lung injury $[17,18]$. Therefore, ACE2 plays a pivotal role in the modulation of the two main arms of RAS: the ACE/Ang II/AT1R axis ("classic RAS") and the ACE2/Ang (1-7)/MasR axis ("anti-RAS"). Indeed, ACE2 antagonizes "classic RAS", playing an essential counter- 
regulatory role in the activation of the "anti-RAS" [19]. As SARS-CoV-2 uses ACE2 as a primary receptor to gain entry into human cells, causing its functional down-regulation through internalization and shedding $[20,21]$, coronavirus infection leads to a RAS dysregulation, enhancing the ACE/Ang II/AT1R pathway up to vascular "toxicity", causing microvascular damage and dysregulated vascular permeability. This results in capillary leakage of protein and fibrin-rich edema filling alveolar spaces, also promoting oxidative stress and inflammation, leading to acute respiratory distress syndrome (ARDS) [9]. Moreover, the ACE/Ang II/AT1R axis is likely to promote the production of inflammatory cytokines, accelerate apoptosis in alveolar epithelial cells and promote extracellular matrix synthesis, resulting in lung fibrosis, a hallmark of tissue injury in SARS-CoV-2-related pneumonia [22]. On the other hand, Ang (1-7) has been found to mitigate inflammation, counteract lung fibrosis, and improve oxygenation in acute lung injury, acting as a protective factor against ARDS [17]. The main cardio-metabolic conditions associated with a worse outcome in COVID-19 are intertwined via RAS imbalance at baseline. We will discuss these conditions one by one in the following sections, assuming a key role of the disequilibrium between "classic" RAS and "anti-RAS" as common denominators in the development of severe COVID-19.

\section{Overweight, Obesity, Visceral Adiposity and Metabolic Syndrome}

Several studies have focused on the association between obesity and adverse outcomes in patients hospitalized for COVID-19. A first meta-analysis [23] analyzed five different cohorts between January and May 2020, finding how patients with higher body mass index (BMI) had a greater risk for intensive care unit (ICU) admission and for invasive mechanical ventilation. Further meta-analyses have corroborated these findings [24-26]. A retrospective cohort study reported that the proportion of patients who required invasive mechanical ventilation increased according to BMI, and it was greatest in patients with BMI $\geq 35 \mathrm{~kg} / \mathrm{m}^{2}$ [27]. A recent large prospective, community-based, cohort study on patients from over 1500 English general practitioners found J-shaped associations between BMI and hospital admission or death due to COVID-19 and a linear association between BMI and ICU admission [28]. The authors reported that each excess BMI unit above a BMI of $23 \mathrm{~kg} / \mathrm{m}^{2}$ was associated with progressively increased hazard ratio of adverse COVID-19 outcomes (hospital admission, ICU admission, death). Interestingly, this association was amplified for people of black ethnicity compared with those of white ethnicity and for younger people (aged 20-39 years) compared with older people (aged $\geq 80$ years) [28]. In addition to data concerning obesity, fat deposition in the abdominal region (visceral fat) and in ectopic sites such as liver, epicardium, and skeletal muscle, was identified as independent risk factor for worse severity of COVID-19. Indeed, higher visceral fat has been reported to be associated with an increased need of intensive care in both subjects older than 65 years and males [29]. Furthermore, the risk due to obesity in COVID-19 has been found to be significantly greater in obese patients with metabolic associated fatty liver disease (MAFLD) [30]. The visceral fat is an important component of metabolic syndrome (MetS), another condition associated with poor prognosis in COVID-19. In previous case series, the prevalence of MetS in hospitalized COVID-19 patients was up to $81 \%$, with a five-fold greater risk of disease deterioration and increased mortality risk as the MetS components count increased [31,32].

Obesity and overweight with visceral adiposity promote increased circulating levels of Ang I, leading to an overproduction of Ang II and hyper-activation of "classic RAS" [33,34]. Adipocytes produce and release all the components of "classic RAS", including angiotensinogen, ACE, and Ang II, with the only exception of renin, even if they express the renin receptor [35,36]. Thus, in the context of the aforementioned SARS-CoV2-induced ACE2 downregulation, it is likely that the increased levels of both Ang I and Ang II coming from visceral adipose tissue lead to an ACE/Ang II/AT1R "storm" affecting the pulmonary microcirculation in obese COVID-19 patients [37]. In addition, obese subjects show high circulating levels of microRNAs involved in the downregulation of 
ACE2, resulting in further basal dysfunction of ACE2 compared to healthy subjects [38]. Adipose tissue is also involved in cytokine and adipokine secretion, contributing to a pro-inflammatory environment. Indeed, leptin, one of the main adipokines secreted by adipocytes, has been found to be related to increased Ang II levels and decreased ACE2 expression [39]. Moreover, the deficiency of the natriuretic peptide (NP) system, found in obese subjects, mainly due to an increased expression of the clearance NP receptor C [40], could further contribute to the RAS imbalance in this population. In fact, both A-type (ANP) and B-type (BNP) NPs counteract the typical features of the ACE/Ang II/AT1R axis hyper-activation (endothelial dysfunction and increased permeability, pro-inflammatory, pro-hypertrophic, and pro-fibrotic activity), while experimental studies found that ANP can prevent the reduction in ACE2 mediated by Ang II and, conversely, Ang (1-7) can increase ANP release [34,41]. These interactions with RAS, together with their natriuretic and cardio-protective effects against acute cardiac dysfunction that may develop during SARS-CoV-2 infection, give NPs an important role in COVID-19, especially if obesity and heart failure are present [42].

Overall, obesity and overweight can increase the risk for severe COVID-19 through several mechanistic, biochemical, and immunological pathways; among them, the dysregulation of RAS is likely to play a key role in increasing both disease severity and mortality (Figure 1).

\section{"Classic RAS" inappropriate activation in overweight-obese patients with "overflow" in the lungs and further unbalancing due to ACE2 deficit caused by SARS-CoV-2}

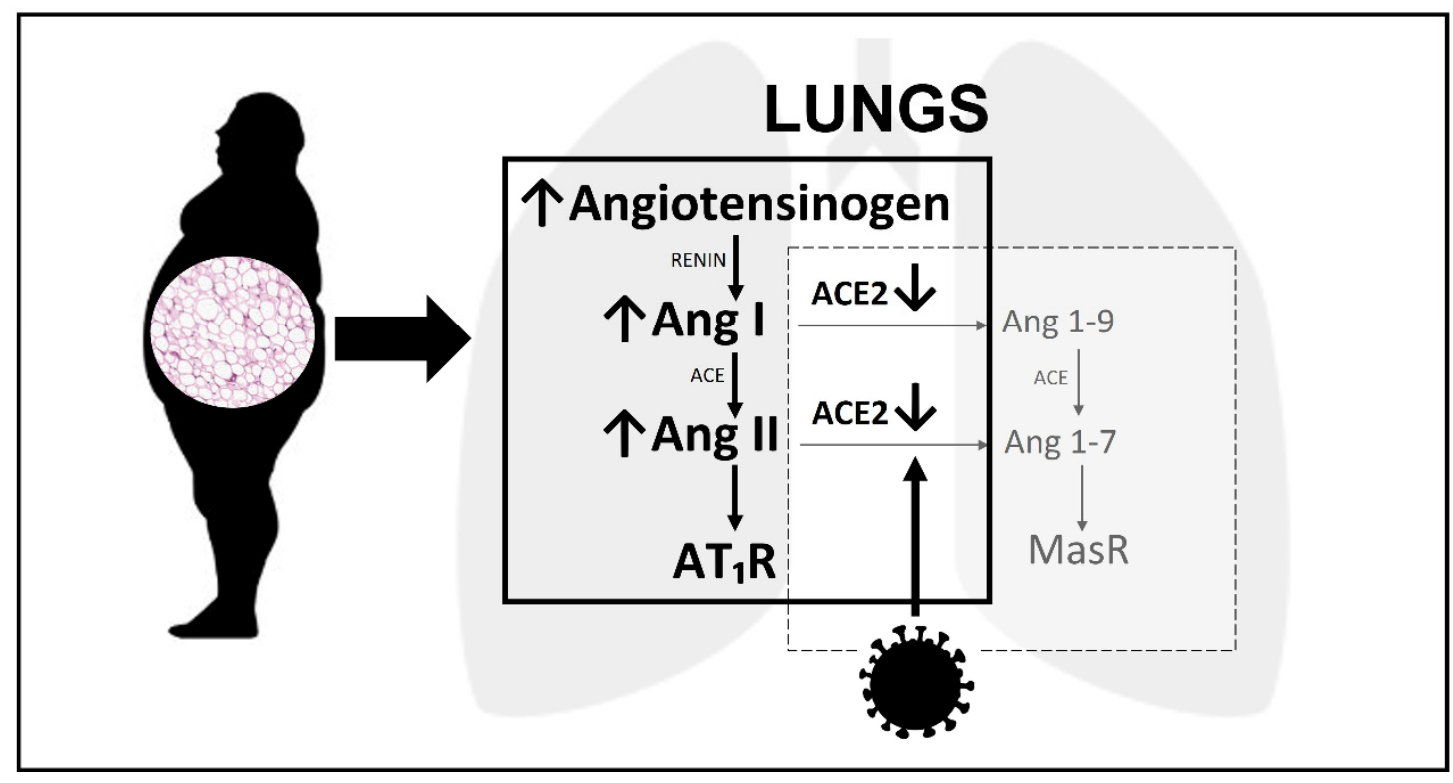

Figure 1. Overweight/obesity, renin-angiotensin-system, and lung injury caused by SARS-CoV-2. ACE, angiotensinconverting-enzyme; Ang, angiotensin; AT1R, angiotensin II type 1 receptor; Mas R, Mas receptor.

\section{Type 2 Diabetes Mellitus}

Type 2 diabetes mellitus was identified early as a metabolic risk factor associated with severe COVID-19. A large meta-analysis that included 33 case-control studies, published between January and April 2020, has reported that diabetes was significantly associated with COVID-19 mortality with a pooled odds ratio of 1.90. Diabetes mellitus was also associated with severe COVID-19 with a pooled odds ratio of 2.75 [43]. The National Cohort Study in England investigated 19,256 COVID-19-related ICU admissions and reported that patients with diabetes were at increased risk of mortality independently of other comorbidities, such as hypertension, chronic obstructive pulmonary disease, heart failure, and chronic renal disease [44]. In a Chinese retrospective cohort study [45], 
diabetes has been found to be independently related with adverse outcomes in COVID-19, while hypertension only when associated with diabetes was an independent predictor of mortality and ARDS. A report from 1590 COVID-19 patients in China found that diabetes was significantly more prevalent among patients with a worse course of disease than among patients with a less severe form (34.6\% vs. $14.3 \%)$, being a risk factor for ICU admission and mortality [46].

New-onset hyperglycemia or acute decompensated diabetes mellitus have been frequently observed in COVID-19 patients [47,48]. Moreover, susceptibility to other overlapped secondary infections, together with the use of glucocorticoid therapy, can further precipitate acute hyperglycemia [49] with increased plasma osmolality, osmotic polyuria and dehydration, endothelial dysfunction, thrombophilia, and amplified pro-inflammatory cytokine secretion, all key factors in SARS-CoV-2-related multi-organ dysfunction. In addition, binding of SARS-CoV-2 to ACE2 in pancreatic cells can damage islets and reduce insulin release, leading to acute hyperglycemia and transient diabetes [50]. The evidence that diabetes mellitus causes a pro-inflammatory environment has been corroborated by serum levels of inflammation biomarkers, such as interleukin-6 (IL-6), C-reactive protein (CRP), and ferritin, and D-dimer that are markedly higher in COVID-19 patients with diabetes mellitus compared to controls without diabetes [51]. Generally, diabetes mellitus is associated with weakened immune response and enhanced susceptibility to infections, due to inherent neutrophil dysfunction, reduced T-cell responses, and disordered humoral immunity [52]. As other cardio-metabolic comorbidities, type 2 diabetes mellitus bears the fingerprint of RAS imbalance: indeed, chronic activation of "classic RAS" is typical in diabetes and insulin-resistance, despite high sodium intake and high blood pressure, and contributes to microvascular and macrovascular complications and is clearly involved in diabetic kidney disease [53]. Furthermore, chronic hyperglycemia also reduces the ACE2 expression, with a loss of its anti-inflammatory effects and protection of endothelial function, because of a decreased counter-regulation of Ang II [54,55].

In the context of ACE/Ang II/AT1R axis hyper-activation, the insulin receptor also uses mitogen-activated protein (MAP) kinase as a downstream mediator of its action [35], mediating growth-factor-like effects, such as vascular smooth muscle growth and cardiac hypertrophy [56]. Even AT1R can activate MAP kinase in its post-receptor cascade, so it can be postulated that these two receptors synergize to exacerbate and perpetuate inflammation, fibrosis, and tissue injury. These findings are in line with the hypothesis that RAS dysregulation could be the backbone in the pathogenesis of severe COVID-19 in patients with diabetes mellitus. This vulnerability may play a synergistic role with the underpinning inflammatory milieu and immune defects associated with diabetes, providing SARS-CoV-2 a pathway for causing prolonged lung injury.

\section{Arterial Hypertension}

Worldwide epidemiologic data provided evidence that hypertension is a pivotal comorbidity related to COVID-19 disease severity. A large meta-analysis [57], including 12 studies on 2389 COVID-19 patients (674 severe cases) found that the severity rate of COVID-19 in hypertensive patients was much higher than in non-hypertensive cases $(37.58 \%$ vs $19.73 \%)$. Moreover, hypertensive patients showed a nearly three-fold higher risk of dying from COVID-19. A community-based observational study [58] examined 1449 hospitalized and non-hospitalized COVID-19 patients in central Massachusetts and found that hypertension was associated with severe outcomes among patients younger than 65 years of age. The results of a meta-analysis, including 60 studies with a total of 51,225 patients hospitalized with COVID-19, are in line with these findings, providing evidence that hypertension was significantly associated with mortality in patients with a mean age $<60$ years (OR 3.7) [59]. In another review [60] on 15,794 participants, hypertension has been found to be a significant predictor of ICU admission and mortality. Another retrospective observational study has examined 2877 consecutive patients admitted to Huo Shen Shan Hospital in Wuhan. The authors reported a two-fold increase in the relative 
risk of mortality in hypertensive individuals compared to non-hypertensive patients. Additionally, hypertensive patients who were not taking anti-hypertensive therapy had a significantly higher risk of mortality than patients on treatment [61].

In addition to the hypertensive condition, anti-hypertensive therapy is also likely to affect the course of COVID-19. A large amount of data from both retrospective and prospective studies provided evidence that patients treated with RAS inhibitors [ACEinhibitors (ACEIs) and angiotensin receptor blockers (ARBs)] tended to have a lower risk of mortality than patients treated with other drugs, disproving initial fears arisen from a possible hyper-production of ACE2 induced by RAS inhibitors, resulting in increased susceptibility to SARS-CoV-2 infection. A large meta-analysis enrolling 101,949 COVID-19 patients found a significant association between treatment with RAS inhibitors and mortality reduction among patients with hypertension [62]. Two nationwide cohort studies, conducted in France and Sweden, reported that taking RAS inhibitors was associated with a lower risk of COVID-19 hospitalization and death [63,64]. An analysis of the HOPE COVID-19 registry revealed that patients receiving RAS inhibitors had lower mortality, ICU admission, and need for mechanical ventilation [65], while an Italian nationwide observational study conducted by the Italian Society of Hypertension found that ACEIs/ARBs did not affect the risk of more severe COVID-19 [66,67]. A French observational study, conducted in a geriatric department, also showed a lower mortality rate in oldest old patients (mean age: $86.3 \pm 8.0$ years) taking ACEIs/ARBs compared with patients not taking these drug classes [68]. These data on older subjects have been confirmed by other observational studies on hospitalized patients, providing additional evidence on the benefit of RAS inhibitor use in this peculiar population [69,70]. On the other side, ACEIs/ARBs withdrawal was found to be associated with greater risk for complications and mortality in hospitalized COVID-19 patients that were previously taking these drugs, as per indication [71], while several large systematic reviews and cohort studies showed how their assumption/continuation was not harmful, firmly advising against their discontinuation [72-75].

The mechanisms by which hypertension leads to increased risk of worse outcome in COVID-19 are likely to be many. Hypertension is a major cardiovascular risk factor that promotes arteriosclerosis of large and small arteries and accelerates atherosclerosis, leading to cardiovascular disease and death. Left ventricular hypertrophy and myocardial fibrosis, with increased filling pressures and impaired coronary reserve, are key features that contribute to atrial fibrillation, myocardial ischemia, and heart failure with preserved ejection fraction [76]. Certainly, RAS hyper-activation or, at least, "inappropriately normal" renin activity and aldosterone levels are typical of overweight/obese hypertensive patients [33]. In these patients, normal or increased Ang II production results in a stimulation of the ACE/Ang II/AT1R pathway, leading to small arteries constriction, hypertrophy, fibrosis, and tissue injury [77]. It also leads to the activation of NADPH oxidases, with subsequent generation of reactive oxygen species, protein oxidation, and dysregulated cell signaling [78]. Moreover, animal models support a hypothetical link between hypertension and reduced ACE2 expression, corroborated by data showing lower expression of ACE2 mRNA and ACE2 protein expression in the kidneys of hypertensive rats [79].

Several findings in animal models $[80,81]$ and humans $[82,83]$ showed how the expression of ACE2 could increase, at least in some organs, after the introduction of ACEIs or ARBs therapy [84]. In any case, ACEIs and ARBs facilitate ACE2 activity with a rebalancing of the "anti-RAS" arm. Indeed, treatment with ARBs can counteract the RAS imbalance through AT1R blockade, while treatment with ACEIs can increase the availability of Ang (1-9) and decrease the degradation of Ang (1-7) [9]. These mechanisms are in agreement with clinical data of a better outcome in COVID-19 patients treated with RAS inhibitors, likely thanks to the rebalancing of the two RAS arms, in addition to the well-known protective effects on the heart and cardiovascular system. 


\section{Dyslipidemia}

Another risk factor often associated with overweight/obesity and MetS is dyslipidemia. Although its influence may vary, according to age and the presence of other comorbidities, meta-analyses found that dyslipidemia was associated with higher mortality and disease severity $[85,86]$. Atherogenic dyslipidemia was more frequent in patients with critical COVID-19 and was significantly associated with intubation and death. High triglycerides levels were associated with high levels of inflammatory biomarkers and poor COVID-19 outcome during hospitalization [87]. A retrospective study also found that decreased serum high-density lipoprotein (HDL) cholesterol levels were associated with COVID-19 severity [88]. Surely, HDL are very complex lipoproteins exerting several functions that go beyond lipid transport and metabolism, and, perhaps, future studies could give a more accurate explanation of these findings.

On the other side, statins, cornerstone drugs in dyslipidemia and cardiovascular disease, demonstrated significant beneficial effects in patients with COVID-19, reducing in-hospital mortality in several observational studies [89-91] and meta-analyses [92,93], although not all studies are in agreement [94]. These beneficial properties, already suggested in previous studies on hospitalized patients [69], might be mediated by their speculative pleiotropic effects, including anti-inflammatory, immunomodulatory, and antithrombotic properties, but the atherosclerotic plaques stabilization, thus avoiding acute cardiovascular ischemic events that often complicate severe COVID-19, is likely to play the key role [70,95-98]. Moreover, several experimental models pointed out their possible inhibitory action on the "classic RAS", ameliorating Ang II-mediated cardiac hypertrophy and fibrosis [98,99]. In experimental models, statins also promote ACE2 up-regulation via inhibition of the MYD88-NF-kB pro-inflammatory pathway [100].

All these data highlight the association between dyslipidemia, the use of lipidlowering drugs, and COVID-19 severity. Further studies are needed to clarify this linkage, but disposable evidence suggests that dyslipidemia, with its related cardiovascular risk, often reported in obese, diabetic, and hypertensive subjects [101], is a real further risk factor for severe COVID-19 more than a simple biomarker of obesity-related dysmetabolism.

\section{Male Sex}

From the early phases of the pandemic, male sex has been found to be associated to a more severe course of COVID-19 and greater need for intensive care, compared with female sex [102]. Studies found how men had a 59\% increased risk for severe outcomes compared to women [103]. Observational studies reported how the vast majority (82\%) of patients that needed intensive care were males [104] and how the main determinants of ICU admission were male sex and obesity [105]. In a study on 4062 hospitalized COVID-19 patients in New York City, males had a higher risk of mortality compared to females and were more likely to present with sepsis and hypoxia on admission [106]. A large metaanalysis [107], including 3,111,714 reported global cases of COVID-19, found that males had higher risk of both ICU admission and death compared to females, although no difference has been found in the proportion of males and females infected with SARS-CoV-2.

Several factors can explain this sex difference. Although the greatest evidence on RAS and sex comes from preclinical studies, both types of sex hormones, estrogens and androgens, likely affect the expression and activity of several RAS components, especially regarding the "classic RAS" pathway, while limited data are available on the interactions with the counter-regulatory RAS components [108]. Estradiol is likely to cause a protective shift in ACE/ACE2 ratio, by both increasing ACE2 and inhibiting ACE expression [109]. Estrogenic activity has been found to inhibit the hemodynamic effects of Ang II and promote the action of ACE2/Ang (1-7) axis in animal models [110]. Estrogen has also been found to decrease tissue AT1R expression and aldosterone production, while testosterone conversely increases ACE activity and tissue AT1R expression [108]. Furthermore, the gene for ACE2 is located in the X chromosome, which could make it susceptible to escaping $X$-inactivation in women [111]. In an animal model of obesity-associated hypertension, the 
increase in blood pressure after high-fat diet is attenuated in females compared to males, and this different behavior appears to be mediated by ACE2 activity [112]. In humans, men tend to have higher levels of aldosterone than females, regardless of other confounders, facilitated, at least in part, by higher levels of endogenous Ang II [113].

Further studies are needed to disclose all the mechanisms underlying this sex difference, but it appears reasonable that the sex-specific RAS regulation contributes to female protection from severe COVID-19, as well as from some cardio-metabolic conditions found more frequently in men [108,114].

\section{Older Age}

Since the beginning of the pandemic, older age, besides the presence of comorbidities, has been clearly associated with a worse outcome in COVID-19 [67]. In China, data collected by the WHO revealed that the majority of deceased patients with COVID-19 were 70 years or older. Another report from the Chinese Centre for Disease Control and Prevention found that fatality rates were $8 \%$ and $15 \%$ among people aged 70 to 79 years and 80 years or older, respectively, while case fatality rate among the entire cohort was 2.3\% [115]. Palmieri et al. [116] examined the characteristics of 35,595 cases of COVID-19-related deaths in Italy from March 2020 to August 2020, finding that the median age was 80.2, with 57.3\% of males; interestingly, they also reported that, in the second phase of the pandemic (JuneAugust 2020), deceased patients with COVID-19 were significantly older (median age 82.8) and with a greater burden of comorbidities. Another Italian study [104] has evaluated a cohort of 3988 critically ill patients with COVID-19 admitted to ICU in Lombardy region, from February 2020 to April 2020; at the multivariate analysis, they found that age over 69 years (hazard ratio 4.25) and male sex (hazard ratio 1.22) were significantly associated with mortality. Furthermore, they also confirmed that hypertension, hypercholesterolemia, heart disease, and diabetes were associated with increased mortality. A large populationbased study reported how older age was strongly associated to increased risk of COVID19-related death: the risk increased with increasing age, up to 20-fold for subjects aged $\geq 80$ years compared with subjects aged 50-59 years, independently of comorbidities and other confounders [103]. A post-hoc analysis of the international, multicenter HOPE COVID-19 registry has selected all patients aged $\geq 65$ years hospitalized for COVID-19, reporting that patients aged 75 years and older had more in-hospital complications and a significantly higher mortality. Their most prevalent comorbidities were hypertension (69.2\%), dyslipidemia (48.6\%), heart disease (38.4\%), and chronic lung disease (25.3\%) [117].

Several factors and age-related modifications are responsible for the increased risk of severe COVID-19 and death in older patients: the large spectrum of multiple cardiometabolic morbidities, leading to a much higher cardiovascular risk, as well as immunesenescence, endothelial dysfunction, limited organ reserve (especially diminished cardiorespiratory function), and other psychosocial and nutritional factors [118]. In this large variety of factors, age-related decline in ACE2 expression, as observed in the lungs of rats [119], may play a non-negligible role. In older people, especially those with cardiovascular comorbidities, reduced ACE2 levels and increased Ang II signaling arrange a pro-inflammatory background. When these subjects are infected with SARS-CoV-2, that leads to a further reduction in ACE2 cell surface expression, there is a consequent overwhelmed amplification of the ACE/Ang II/AT1R pathway that perpetrates microvascular damage and inflammatory effects leading to severe lung injury [120]. It must be recalled that aging has a major role in cardiovascular disease by substantially "giving time" to multiple risk factors, even "borderline" in severity, to produce vascular damage through decades of inappropriate control [121]. When infections strike these older patients, the clinical scenario may often complicate with acute cardiovascular events, leading to more severe clinical course and worse outcome. Furthermore, other conditions often resulting from poor control of cardio-metabolic risk factors, such as chronic kidney disease and vascular dementia, are highly prevalent in older subjects, and are major contributors of severe COVID-19 and death [117]. However, the disequilibrium between ACE and ACE2 
activity, a pathophysiological feature of aging, is likely to play a key role in determining the disease severity in older people affected by COVID-19 [67].

\section{Conclusions}

Titanic efforts have been made, and they are incessantly extended, to understand the pathophysiological mechanisms of COVID-19 in order to prevent its consequences. In this context, our work provides a pathophysiological link that combines several features of patients at higher risk of developing severe complications and dying from SARS-CoV-2 infection, based on RAS dysregulation, which is typical not only of severe COVID-19 but also of the most prevalent cardio-metabolic conditions. Therefore, we can draw a particular phenotype, an "identikit" of the patient characterized by male sex, older age, features of MetS (excessive visceral adiposity with insulin resistance, altered glucose, and lipid metabolism), and arterial hypertension (Figure 2), aiming at detecting patients at higher risk for severe COVID-19 and death. Ad-hoc studies that develop a risk score based on the risk factors taken into account in the present review may allow a rapid identification of these patients, with possible benefits in terms of resource allocation and prognosis. Further studies are needed, to better clarify the pathophysiological bases of COVID-19, in order to arrange more effective instruments of prevention and care that could help us to reduce morbidity and mortality in the long struggle with this tremendous plague. At the moment, the most rational and evidence-based link between the common cardio-metabolic conditions and severe COVID-19 is the one based on the dysregulation of RAS.

\section{Risk factors for severe COVID-19 linked by the ACE/Ang II/AT1R axis hyperactivation fil rouge}

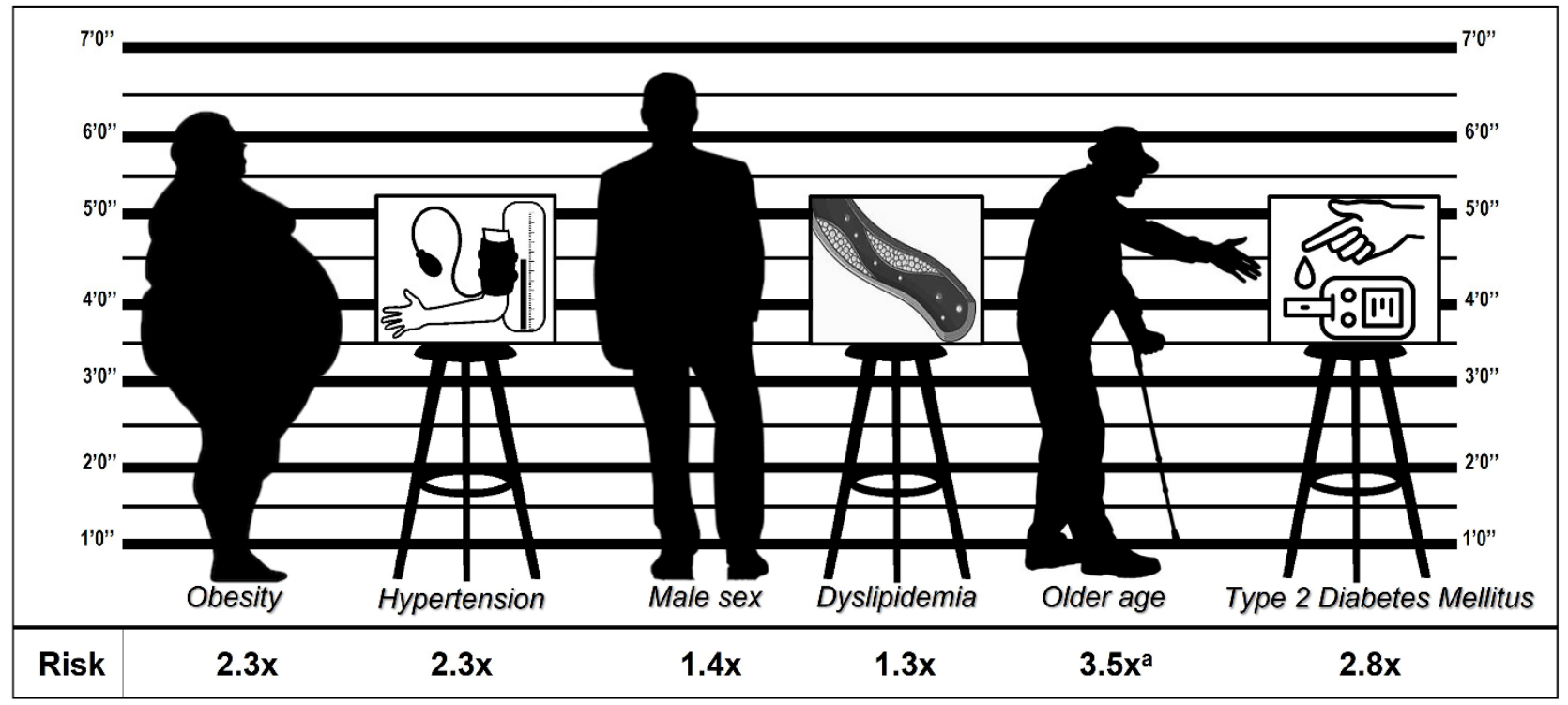

Figure 2. Identikit of the patient at risk for severe COVID-19: "classic RAS" inappropriate activation in a context of lower ACE2 activity as a common feature. Health conditions, cardiometabolic comorbidities, and their assumed relative risk $[5,25,43,85,107,117]$. a: for patients aged $\geq 75$ years.

Author Contributions: Conceptualization, R.S. and F.S.; writing-original draft preparation, M.A., S.R., P.G., C.D.P.; writing-review and editing, F.G., F.S.; supervision, R.S. and F.S. All authors have read and agreed to the published version of the manuscript.

Funding: This research was funded by University "Politecnica delle Marche" (Ricerca Scientifica di Ateneo to Riccardo Sarzani). This research received no external funding.

Data Availability Statement: No new data were created or analyzed in this study. Data sharing is not applicable to this article. 
Conflicts of Interest: The authors declare no conflict of interest.

\section{References}

1. Lu, R.; Zhao, X.; Li, J.; Niu, P.; Yang, B.; Wu, H.; Wang, W.; Song, H.; Huang, B.; Zhu, N.; et al. Genomic characterisation and epidemiology of 2019 novel coronavirus: Implications for virus origins and receptor binding. Lancet 2020, 395, 565-574. [CrossRef]

2. Barison, A.; Aimo, A.; Castiglione, V.; Arzilli, C.; Lupón, J.; Codina, P.; Santiago-Vacas, E.; Cediel, G.; Emdin, M.; Bayes-Genis, A. Cardiovascular disease and COVID-19: Les liaisons dangereuses. Eur. J. Prev. Cardiol. 2020, 27, 1017-1025. [CrossRef] [PubMed]

3. Wang, D.; Hu, B.; Hu, C.; Zhu, F.; Liu, X.; Zhang, J.; Wang, B.; Xiang, H.; Cheng, Z.; Xiong, Y.; et al. Clinical Characteristics of 138 Hospitalized Patients With 2019 Novel Coronavirus-Infected Pneumonia in Wuhan, China. JAMA 2020, 323, 1061-1069. [CrossRef] [PubMed]

4. $\quad$ Richardson, S.; Hirsch, J.S.; Narasimhan, M.; Crawford, J.M.; McGinn, T.; Davidson, K.W.; Barnaby, D.P.; Becker, L.B.; Chelico, J.D.; Cohen, S.L.; et al. Presenting Characteristics, Comorbidities, and Outcomes Among 5700 Patients Hospitalized With COVID-19 in the New York City Area. JAMA 2020, 323, 2052-2059. [CrossRef]

5. Meng, M.; Zhao, Q.; Kumar, R.; Bai, C.; Deng, Y.; Wan, B. Impact of cardiovascular and metabolic diseases on the severity of COVID-19: A systematic review and meta-analysis. Aging 2020, 12, 23409-23421. [CrossRef]

6. Hernández-Garduño, E. Obesity is the comorbidity more strongly associated for Covid-19 in Mexico. A case-control study. Obes. Res. Clin. Pract. 2020, 14, 375-379. [CrossRef]

7. Hoffmann, M.; Kleine-Weber, H.; Schroeder, S.; Krüger, N.; Herrler, T.; Erichsen, S.; Schiergens, T.S.; Herrler, G.; Wu, N.-H.; Nitsche, A.; et al. SARS-CoV-2 Cell Entry Depends on ACE2 and TMPRSS2 and Is Blocked by a Clinically Proven Protease Inhibitor. Cell 2020, 181, 271-280. [CrossRef]

8. Sarzani, R.; Giulietti, F.; Di Pentima, C.; Giordano, P.; Spannella, F. Severe acute respiratory syndrome coronavirus 2 infection, angiotensin-converting enzyme 2 and treatment with angiotensin-converting enzyme inhibitors or angiotensin II type 1 receptor blockers. Eur. J. Prev. Cardiol. 2020, 15, 2047487320918421. [CrossRef]

9. Sarzani, R.; Giulietti, F.; Di Pentima, C.; Giordano, P.; Spannella, F. Disequilibrium between the classic renin-angiotensin system and its opposing arm in SARS-CoV-2-related lung injury. Am. J. Physiol. Lung Cell. Mol. Physiol. 2020, 319, L325-L336. [CrossRef]

10. Wiener, R.S.; Cao, Y.X.; Hinds, A.; Ramirez, M.I.; Williams, M.C. Angiotensin converting enzyme 2 is primarily epithelial and is developmentally regulated in the mouse lung. J. Cell. Biochem. 2007, 101, 1278-1291. [CrossRef] [PubMed]

11. Santos, R.A.S.; Oudit, G.Y.; Verano-Braga, T.; Canta, G.; Steckelings, U.M.; Bader, M. The renin-angiotensin system: Going beyond the classical paradigms. Am. J. Physiol. Heart Circ. Physiol. 2019, 316, H958-H970. [CrossRef] [PubMed]

12. Voors, A.A.; Pinto, Y.M.; Buikema, H.; Urata, H.; Oosterga, M.; Rooks, G.; Grandjean, J.G.; Ganten, D.; van Gilst, W. Dual pathway for angiotensin II formation in human internal mammary arteries. Br. J. Pharmacol. 1998, 125, 1028-1032. [CrossRef]

13. Ferrario, C.M.; Trask, A.J.; Jessup, J.A. Advances in biochemical and functional roles of angiotensin-converting enzyme 2 and angiotensin-(1-7) in regulation of cardiovascular function. Am. J. Physiol. Circ. Physiol. 2005, 289, H2281-H2290. [CrossRef] [PubMed]

14. Santos, R.A.S.; Simoes e Silva, A.C.; Maric, C.; Silva, D.M.R.; Machado, R.P.; de Buhr, I.; Heringer-Walther, S.; Pinheiro, S.V.B.; Lopes, M.T.; Bader, M.; et al. Angiotensin-(1-7) is an endogenous ligand for the G protein-coupled receptor Mas. Proc. Natl. Acad. Sci. USA 2003, 100, 8258-8263. [CrossRef]

15. Sanchis-Gomar, F.; Lavie, C.J.; Perez-Quilis, C.; Henry, B.M.; Lippi, G. Angiotensin-Converting Enzyme 2 and Antihypertensives (Angiotensin Receptor Blockers and Angiotensin-Converting Enzyme Inhibitors) in Coronavirus Disease 2019. Mayo Clin. Proc. 2020, 95, 1222-1230. [CrossRef]

16. Arendse, L.B.; Danser, A.H.J.; Poglitsch, M.; Touyz, R.M.; Burnett, J.C., Jr.; Llorens-Cortes, C.; Ehlers, M.R.; Sturrock, E.D. Novel Therapeutic Approaches Targeting the Renin-Angiotensin System and Associated Peptides in Hypertension and Heart Failure. Pharmacol. Rev. 2019, 71, 539-570. [CrossRef]

17. Zambelli, V.; Bellani, G.; Borsa, R.; Pozzi, F.; Grassi, A.; Scanziani, M.; Castiglioni, V.; Masson, S.; Decio, A.; Laffey, J.G.; et al. Angiotensin-(1-7) improves oxygenation, while reducing cellular infiltrate and fibrosis in experimental Acute Respiratory Distress Syndrome. Intensiv. Care Med. Exp. 2015, 3, 44. [CrossRef] [PubMed]

18. Imai, Y.; Kuba, K.; Rao, S.; Huan, Y.; Guo, F.; Guan, B.; Yang, P.; Sarao, R.; Wada, T.; Leong-Poi, H.; et al. Angiotensin-converting enzyme 2 protects from severe acute lung failure. Nature 2005, 436, 112-116. [CrossRef]

19. Paz Ocaranza, M.; Riquelme, J.A.; García, L.; Jalil, J.E.; Chiong, M.; Santos, R.A.S.; Lavandero, S. Counter-regulatory reninangiotensin system in cardiovascular disease. Nat. Rev. Cardiol. 2020, 17, 116-129. [CrossRef]

20. Samavati, L.; Uhal, B.D. ACE2, Much More Than Just a Receptor for SARS-COV-2. Front. Cell. Infect. Microbiol. 2020, 10, 317. [CrossRef] [PubMed]

21. Glowacka, I.; Bertram, S.; Herzog, P.; Pfefferle, S.; Steffen, I.; Muench, M.O.; Simmons, G.; Hofmann, H.; Kuri, T.; Weber, F.; et al. Differential downregulation of ACE2 by the spike proteins of severe acute respiratory syndrome coronavirus and human coronavirus NL63. J. Virol. 2010, 84, 1198-1205. [CrossRef] [PubMed]

22. Uhal, B.D.; Li, X.; Piasecki, C.C.; Molina-Molina, M. Angiotensin signalling in pulmonary fibrosis. Int. J. Biochem. Cell Biol. 2012, 44, 465-468. [CrossRef] 
23. Földi, M.; Farkas, N.; Kiss, S.; Zádori, N.; Váncsa, S.; Szakó, L.; Dembrovszky, F.; Solymár, M.; Bartalis, E.; Szakács, Z.; et al. Obesity is a risk factor for developing critical condition in COVID-19 patients: A systematic review and meta-analysis. Obes. Rev. 2020, 21, e13095. [CrossRef] [PubMed]

24. Huang, Y.; Lu, Y.; Huang, Y.-M.; Wang, M.; Ling, W.; Sui, Y.; Zhao, H.-L. Obesity in patients with COVID-19: A systematic review and meta-analysis. Metabolism 2020, 113, 154378. [CrossRef] [PubMed]

25. Yang, J.; Hu, J.; Zhu, C. Obesity aggravates COVID-19: A systematic review and meta-analysis. J. Med. Virol. 2021, 93, 257-261. [CrossRef]

26. Popkin, B.M.; Du, S.; Green, W.D.; Beck, M.A.; Algaith, T.; Herbst, C.H.; Alsukait, R.F.; Alluhidan, M.; Alazemi, N.; Shekar, M. Individuals with obesity and COVID-19: A global perspective on the epidemiology and biological relationships. Obes. Rev. 2020, 21, e13128. [CrossRef]

27. Simonnet, A.; Chetboun, M.; Poissy, J.; Raverdy, V.; Noulette, J.; Duhamel, A.; Labreuche, J.; Mathieu, D.; Pattou, F.; Jourdain, M.; et al. High Prevalence of Obesity in Severe Acute Respiratory Syndrome Coronavirus-2 (SARS-CoV-2) Requiring Invasive Mechanical Ventilation. Obesity 2020, 28, 1994. [CrossRef]

28. Gao, M.; Piernas, C.; Astbury, N.M.; Hippisley-Cox, J.; O’Rahilly, S.; Aveyard, P.; Jebb, S.A. Associations between body-mass index and COVID-19 severity in 6.9 million people in England: A prospective, community-based, cohort study. Lancet Diabetes Endocrinol. 2021, 9, 350-359. [CrossRef]

29. Watanabe, M.; Caruso, D.; Tuccinardi, D.; Risi, R.; Zerunian, M.; Polici, M.; Pucciarelli, F.; Tarallo, M.; Strigari, L.; Manfrini, S.; et al. Visceral fat shows the strongest association with the need of intensive care in patients with COVID-19. Metabolism 2020, 111, 154319. [CrossRef]

30. Zheng, K.; Gao, F.; Wang, X.-B.; Sun, Q.-F.; Pan, K.-H.; Wang, T.-Y.; Ma, H.-L.; Chen, Y.-P.; Liu, W.-Y.; George, J.; et al. Letter to the Editor: Obesity as a risk factor for greater severity of COVID-19 in patients with metabolic associated fatty liver disease. Metabolism 2020, 108, 154244. [CrossRef]

31. Ouedraogo, E.; Allard, L.; Bihan, H.; de Bouillé, J.G.; Giroux-Leprieur, B.; Sutton, A.; Baudry, C.; Josse, C.; Didier, M.; Deutsch, D.; et al. The association of metabolic syndrome and COVID-19 deterioration. Nutr. Metab. Cardiovasc. Dis. 2021, 31, 3236-3242. [CrossRef]

32. Alamdari, N.M.; Rahimi, F.S.; Afaghi, S.; Zarghi, A.; Qaderi, S.; Tarki, F.E.; Ghafouri, S.R.; Besharat, S. The impact of metabolic syndrome on morbidity and mortality among intensive care unit admitted COVID-19 patients. Diabetes Metab. Syndr. Clin. Res. Rev. 2020, 14, 1979-1986. [CrossRef]

33. Sarzani, R.; Salvi, F.; Dessì-Fulgheri, P.; Rappelli, A. Renin-angiotensin system, natriuretic peptides, obesity, metabolic syndrome, and hypertension: An integrated view in humans. J. Hypertens. 2008, 26, 831-843. [CrossRef]

34. Sarzani, R.; Spannella, F.; Giulietti, F.; Balietti, P.; Cocci, G.; Bordicchia, M. Cardiac Natriuretic Peptides, Hypertension and Cardiovascular Risk. High Blood Press. Cardiovasc. Prev. 2017, 24, 115-126. [CrossRef]

35. Zhou, M.-S.; Schulman, I.; Zeng, Q. Link between the renin-angiotensin system and insulin resistance: Implications for cardiovascular disease. Vasc. Med. 2012, 17, 330-341. [CrossRef] [PubMed]

36. Achard, V.; Boullu-Ciocca, S.; Desbriere, R.; Nguyen, G.; Grino, M. Renin receptor expression in human adipose tissue. Am. J. Physiol. Integr. Comp. Physiol. 2007, 292, R274-R282. [CrossRef]

37. de Leeuw, A.J.M.; Luttikhuis, M.A.M.O.; Wellen, A.C.; Müller, C.; Calkhoven, C.F. Obesity and its impact on COVID-19. J. Mol. Med. 2021, 99, 899-915. [CrossRef]

38. Papannarao, J.B.; Schwenke, D.O.; Manning, P.; Katare, R. Upregulated miR-200c is associated with downregulation of the functional receptor for severe acute respiratory syndrome coronavirus 2 ACE2 in individuals with obesity. Int. J. Obes. 2021, 1-4. [CrossRef] [PubMed]

39. Ibrahim, H.S.; Froemming, G.; Omar, E.; Singh, H.J. ACE2 activation by xanthenone prevents leptin-induced increases in blood pressure and proteinuria during pregnancy in Sprague-Dawley rats. Reprod. Toxicol. 2014, 49, 155-161. [CrossRef]

40. Sarzani, P.; Dessì-Fulgheri, P.; Paci, V.M.; Espinosa, E.; Rappelli, A. Expression of natriuretic peptide receptors in human adipose and other tissues. J. Endocrinol. Investig. 1996, 19, 581-585. [CrossRef] [PubMed]

41. Shah, A.; Gul, R.; Yuan, K.; Gao, S.; Oh, Y.-B.; Kim, U.-H.; Kim, S.H. Angiotensin-(1-7) stimulates high atrial pacing-induced ANP secretion via Mas/PI3-kinase/Akt axis and Na+/H+ exchanger. Am. J. Physiol. Circ. Physiol. 2010, 298, H1365-H1374. [CrossRef]

42. Rubattu, S.; Gallo, G.; Volpe, M. A Contemporary View of Natriuretic Peptides in the SARS-CoV-2 Era. Front. Physiol. 2021, 12, 643721. [CrossRef] [PubMed]

43. Kumar, A.; Arora, A.; Sharma, P.; Anikhindi, S.A.; Bansal, N.; Singla, V.; Khare, S.; Srivastava, A. Is diabetes mellitus associated with mortality and severity of COVID-19? A meta-analysis. Diabetes Metab. Syndr. Clin. Res. Rev. 2020, 14, 535-545. [CrossRef]

44. Dennis, J.M.; Mateen, B.A.; Sonabend, R.; Thomas, N.J.; Patel, K.A.; Hattersley, A.T.; Denaxas, S.; McGovern, A.P.; Vollmer, S.J. Type 2 Diabetes and COVID-19-Related Mortality in the Critical Care Setting: A National Cohort Study in England, March-July 2020. Diabetes Care 2020, 44, 50-57. [CrossRef] [PubMed]

45. Sun, Y.; Guan, X.; Jia, L.; Xing, N.; Cheng, L.; Liu, B.; Zhang, S.; He, K. Independent and combined effects of hypertension and diabetes on clinical outcomes in patients with COVID-19: A retrospective cohort study of Huoshen Mountain Hospital and Guanggu Fangcang Shelter Hospital. J. Clin. Hypertens. 2020, 23, 218-231. [CrossRef] 
46. Guan, W.-J.; Liang, W.-H.; Zhao, Y.; Liang, H.-R.; Chen, Z.-S.; Li, Y.-M.; Liu, X.-Q.; Chen, R.-C.; Tang, C.-L.; Wang, T.; et al. Comorbidity and its impact on 1590 patients with COVID-19 in China: A nationwide analysis. Eur. Respir. J. 2020, 55, 2000547. [CrossRef] [PubMed]

47. Montefusco, L.; Ben Nasr, M.; D’Addio, F.; Loretelli, C.; Rossi, A.; Pastore, I.; Daniele, G.; Abdelsalam, A.; Maestroni, A.; Dell'Acqua, M.; et al. Acute and long-term disruption of glycometabolic control after SARS-Cov-2 infection. Nat. Metab. 2021, 3, 774-785. [CrossRef] [PubMed]

48. Rubino, F.; Amiel, S.A.; Zimmet, P.; Alberti, G.; Bornstein, S.; Eckel, R.H.; Mingrone, G.; Boehm, B.; Cooper, M.E.; Chai, Z.; et al. New-Onset Diabetes in COVID-19. N. Engl. J. Med. 2020, 383, 789-790. [CrossRef]

49. Sarzani, R.; Spannella, F.; Giulietti, F.; Di Pentima, C.; Giordano, P.; Giacometti, A. Possible harm from glucocorticoid drugs misuse in the early phase of SARS-CoV-2 infection: A narrative review of the evidence. Intern. Emerg. Med. 2021, 1-10. [CrossRef] [PubMed]

50. Yang, J.-K.; Lin, S.-S.; Ji, X.-J.; Guo, L.-M. Binding of SARS coronavirus to its receptor damages islets and causes acute diabetes. Acta Diabetol. 2010, 47, 193-199. [CrossRef]

51. Guo, W.; Li, M.; Dong, Y.; Zhou, H.; Zhang, Z.; Tian, C.; Qin, R.; Wang, H.; Shen, Y.; Du, K.; et al. Diabetes is a risk factor for the progression and prognosis of COVID -19. Diabetes/Metabolism Res. Rev. 2020, 36, e3319. [CrossRef]

52. Katulanda, P.; Dissanayake, H.A.; Ranathunga, I.; Ratnasamy, V.; Wijewickrama, P.S.A.; Yogendranathan, N.; Gamage, K.K.K.; De Silva, N.L.; Sumanatilleke, M.; Somasundaram, N.P.; et al. Prevention and management of COVID-19 among patients with diabetes: An appraisal of the literature. Diabetologia 2020, 63, 1440-1452. [CrossRef] [PubMed]

53. Patel, V.; Parajuli, N.; Oudit, G.Y. Role of angiotensin-converting enzyme 2 (ACE2) in diabetic cardiovascular complications. Clin. Sci. 2014, 126, 471-482. [CrossRef] [PubMed]

54. Bornstein, S.R.; Dalan, R.; Hopkins, D.; Mingrone, G.; Boehm, B.O. Endocrine and metabolic link to coronavirus infection. Nat. Rev. Endocrinol. 2020, 16, 297-298. [CrossRef] [PubMed]

55. Santos, A.; Magro, D.O.; Evangelista-Poderoso, R.; Saad, M.J.A. Diabetes, obesity, and insulin resistance in COVID-19: Molecular interrelationship and therapeutic implications. Diabetol. Metab. Syndr. 2021, 13, 1-14. [CrossRef]

56. Hsueh, W.A.; Quiñones, M.J. Role of endothelial dysfunction in insulin resistance. Am. J. Cardiol. 2003, 92, 10J-17J. [CrossRef]

57. Zhang, J.; Wu, J.; Sun, X.; Xue, H.; Shao, J.; Cai, W.; Jing, Y.; Yue, M.; Dong, C. Association of hypertension with the severity and fatality of SARS-CoV-2 infection: A meta-analysis. Epidemiol. Infect. 2020, 148, e106. [CrossRef]

58. Bauer, A.Z.; Gore, R.; Sama, S.R.; Rosiello, R.; Garber, L.; Sundaresan, D.; McDonald, A.; Arruda, P.; Kriebel, D. Hypertension, medications, and risk of severe COVID-19: A Massachusetts community-based observational study. J. Clin. Hypertens. 2021, 23, 21-27. [CrossRef]

59. Mesas, A.E.; Cavero-Redondo, I.; Álvarez-Bueno, C.; Sarriá Cabrera, M.A.; Maffei de Andrade, S.; Sequí-Dominguez, I.; MartínezVizcaíno, V. Predictors of in-hospital COVID-19 mortality: A comprehensive systematic review and meta-analysis exploring differences by age, sex and health conditions. PLoS ONE 2020, 15, e0241742. [CrossRef]

60. Barrera, F.J.; Shekhar, S.; Wurth, R.; Moreno-Pena, P.J.; Ponce, O.J.; Hajdenberg, M.; Alvarez-Villalobos, N.A.; Hall, J.E.; Schiffrin, E.L.; Eisenhofer, G.; et al. Prevalence of Diabetes and Hypertension and Their Associated Risks for Poor Outcomes in COVID-19 Patients. J. Endocr. Soc. 2020, 4, bvaa102. [CrossRef]

61. Gao, C.; Cai, Y.; Zhang, K.; Zhou, L.; Zhang, Y.; Zhang, X.; Li, Q.; Li, W.; Yang, S.; Zhao, X.; et al. Association of hypertension and antihypertensive treatment with COVID-19 mortality: A retrospective observational study. Eur. Heart J. 2020, 41, $2058-2066$. [CrossRef] [PubMed]

62. Baral, R.; Tsampasian, V.; Debski, M.; Moran, B.; Garg, P.; Clark, A.; Vassiliou, V.S. Association Between Renin-AngiotensinAldosterone System Inhibitors and Clinical Outcomes in Patients With COVID-19. JAMA Netw. Open 2021, 4, e213594. [CrossRef] [PubMed]

63. Semenzato, L.; Botton, J.; Drouin, J.; Baricault, B.; Vabre, C.; Cuenot, F.; Penso, L.; Herlemont, P.; Sbidian, E.; Weill, A.; et al. Antihypertensive Drugs and COVID-19 Risk. Hypertension 2021, 77, 833-842. [CrossRef]

64. Savarese, G.; Benson, L.; Sundström, J.; Lund, L.H. Association between renin-angiotensin-aldosterone system inhibitor use and COVID-19 hospitalization and death: A 1.4 million patient nationwide registry analysis. Eur. J. Heart Fail. 2020, 23, 476-485. [CrossRef] [PubMed]

65. Núñez-Gil, I.J.; Olier, I.; Feltes, G.; Viana-Llamas, M.C.; Maroun-Eid, C.; Romero, R.; Fernández-Rozas, I.; Uribarri, A.; BecerraMuñoz, V.M.; Alfonso-Rodriguez, E.; et al. Renin-angiotensin system inhibitors effect before and during hospitalization in COVID-19 outcomes: Final analysis of the international HOPE COVID-19 (Health Outcome Predictive Evaluation for COVID-19) registry. Am. Heart J. 2021, 237, 104-115. [CrossRef]

66. Mancusi, C.; Grassi, G.; Borghi, C.; Carugo, S.; Fallo, F.; Ferri, C.; Giannattasio, C.; Grassi, D.; Letizia, C.; Minuz, P.; et al. Determinants of healing among patients with coronavirus disease 2019: The results of the SARS-RAS study of the Italian Society of Hypertension. J. Hypertens. 2020, 39, 376-380. [CrossRef]

67. Iaccarino, G.; Grassi, G.; Borghi, C.; Ferri, C.; Salvetti, M.; Volpe, M. Age and Multimorbidity Predict Death among COVID-19 Patients. Hypertension 2020, 76, 366-372. [CrossRef]

68. Genet, B.; Vidal, J.-S.; Cohen, A.; Boully, C.; Beunardeau, M.; Harlé, L.M.; Gonçalves, A.; Boudali, Y.; Hernandorena, I.; Bailly, H.; et al. COVID-19 In-Hospital Mortality and Use of Renin-Angiotensin System Blockers in Geriatrics Patients. J. Am. Med. Dir. Assoc. 2020, 21, 1539-1545. [CrossRef] 
69. Oliveira, J.; Gameiro, J.; Bernardo, J.; Marques, F.; Costa, C.; Branco, C.; Duarte, I.; Fonseca, J.; Carreiro, C.; Braz, S.; et al. Impact of Chronic RAAS Use in Elderly COVID-19 Patients: A Retrospective Analysis. J. Clin. Med. 2021, 10, 3147. [CrossRef] [PubMed]

70. Spannella, F.; Giulietti, F.; Balietti, P.; Cocci, G.; Landi, L.; Lombardi, F.E.; Borioni, E.; Bernardi, B.; Rosettani, G.; Bordoni, V.; et al. Renin-Angiotensin System Blockers and Statins Are Associated With Lower In-Hospital Mortality in Very Elderly Hypertensives. J. Am. Med. Dir. Assoc. 2018, 19, 342-347. [CrossRef] [PubMed]

71. Roy-Vallejo, E.; Purificación, A.S.; Peña, J.D.T.; Moreno, B.S.; Arnalich, F.; Blanco, M.J.G.; Miranda, J.L.; Romero-Cabrera, J.L.; Gil, C.R.H.; Bascunana, J.; et al. Angiotensin-Converting Enzyme Inhibitors and Angiotensin Receptor Blockers Withdrawal Is Associated with Higher Mortality in Hospitalized Patients with COVID-19. J. Clin. Med. 2021, 10, 2642. [CrossRef] [PubMed]

72. Sablerolles, R.S.G.; Hogenhuis, F.E.F.; Lafeber, M.; van de Loo, B.P.A.; Borgsteede, S.D.; Boersma, E.; Versmissen, J.; van der Kuy, H.; COMET Research Team. No association between use of angiotensin-converting enzyme inhibitors or angiotensin II receptor blockers prior to hospital admission and clinical course of COVID-19 in the COvid MEdicaTion (COMET) study. Br. J. Clin. Pharmacol. 2021, 87, 3301-3309. [CrossRef] [PubMed]

73. Bavishi, C.; Whelton, P.K.; Mancia, G.; Corrao, G.; Messerli, F.H. Renin-angiotensin-system inhibitors and all-cause mortality in patients with COVID-19: A systematic review and meta-analysis of observational studies. J. Hypertens. 2021, 39, 784-794. [CrossRef]

74. Lee, M.M.Y.; Docherty, K.F.; Sattar, N.; Mehta, N.; Kalra, A.; Nowacki, A.S.; Solomon, S.D.; Vaduganathan, M.; Petrie, M.C.; Jhund, P.S.; et al. Renin-angiotensin system blockers, risk of SARS-CoV-2 infection and outcomes fromCoViD-19: Systematic review and meta-analysis. Eur. Heart J. Cardiovasc. Pharmacother. 2020. [CrossRef]

75. Morales, D.R.; Conover, M.M.; You, S.C.; Pratt, N.; Kostka, K.; Duarte-Salles, T.; Fernández-Bertolín, S.; Aragón, M.; DuVall, S.L.; Lynch, K.; et al. Renin-angiotensin system blockers and susceptibility to COVID-19: An international, open science, cohort analysis. Lancet Digit. Health 2021, 3, e98-e114. [CrossRef]

76. Sarzani, R.; Bordicchia, M.; Spannella, F.; Dessì-Fulgheri, P.; Fedecostante, M. Hypertensive heart disease and obesity: A complex interaction between hemodynamic and not hemodynamic factors. High Blood Press. Cardiovasc. Prev. 2014, 21, 81-87. [CrossRef] [PubMed]

77. Silva-Aguiar, R.P.; Peruchetti, D.B.; Rocco, P.R.M.; Schmaier, A.H.; e Silva, P.M.R.; Martins, M.A.; Carvalho, V.F.; Pinheiro, A.A.S.; Caruso-Neves, C. Role of the renin-angiotensin system in the development of severe COVID-19 in hypertensive patients. Am. J. Physiol. Lung Cell. Mol. Physiol. 2020, 319, L596-L602. [CrossRef]

78. Wingler, K.; Wünsch, S.; Kreutz, R.; Rothermund, L.; Paul, M.; Schmidt, H.H. Upregulation of the vascular NAD(P)H-oxidase isoforms Nox1 and Nox4 by the renin-angiotensin system in vitro and in vivo. Free Radic. Biol. Med. 2001, 31, 1456-1464. [CrossRef]

79. Crackower, M.A.; Sarao, R.; Oudit, G.Y.; Yagil, C.; Kozieradzki, I.; Scanga, S.E.; Oliveira-dos-Santos, A.J.; da Costa, J.; Zhang, L.; Pei, Y.; et al. Angiotensin-converting enzyme 2 is an essential regulator of heart function. Nature 2002, 417, 822-828. [CrossRef]

80. Ferrario, C.M.; Jessup, J.; Chappell, M.C.; Averill, D.B.; Brosnihan, K.B.; Tallant, E.A.; Diz, D.I.; Gallagher, P.E. Effect of angiotensinconverting enzyme inhibition and angiotensin II receptor blockers on cardiac angiotensin-converting enzyme 2. Circulation 2005, 111, 2605-2610. [CrossRef]

81. Wang, X.; Ye, Y.; Gong, H.; Wu, J.; Yuan, J.; Wang, S.; Yin, P.; Ding, Z.; Kang, L.; Jiang, Q.; et al. The effects of different angiotensin II type 1 receptor blockers on the regulation of the ACE-AngII-AT1 and ACE2-Ang(1-7)-Mas axes in pressure overload-induced cardiac remodeling in male mice. J. Mol. Cell. Cardiol. 2016, 97, 180-190. [CrossRef] [PubMed]

82. Vuille-dit-Bille, R.N.; Camargo, S.M.; Emmenegger, L.; Sasse, T.; Kummer, E.; Jando, J.; Hamie, Q.M.; Meier, C.F.; Hunziker, S.; Forras-Kaufmann, Z.; et al. Human intestine luminal ACE2 and amino acid transporter expression increased by ACE-inhibitors. Amino Acids 2015, 47, 693-705. [CrossRef] [PubMed]

83. Furuhashi, M.; Moniwa, N.; Mita, T.; Fuseya, T.; Ishimura, S.; Ohno, K.; Shibata, S.; Tanaka, M.; Watanabe, Y.; Akasaka, H.; et al. Urinary angiotensin-converting enzyme 2 in hypertensive patients may be increased by olmesartan, an angiotensin II receptor blocker. Am. J. Hypertens. 2015, 28, 15-21. [CrossRef]

84. Michaud, V.; Deodhar, M.; Arwood, M.; Al Rihani, S.B.; Dow, P.; Turgeon, J. ACE2 as a Therapeutic Target for COVID-19; its Role in Infectious Processes and Regulation by Modulators of the RAAS System. J. Clin. Med. 2020, 9, 2096. [CrossRef] [PubMed]

85. Liu, Y.; Pan, Y.; Yin, Y.; Chen, W.; Li, X. Association of dyslipidemia with the severity and mortality of coronavirus disease 2019 (COVID-19): A meta-analysis. Virol. J. 2021, 18, 157. [CrossRef] [PubMed]

86. Atmosudigdo, I.S.; Pranata, R.; Lim, M.A.; Henrina, J.; Yonas, E.; Vania, R.; Radi, B. Dyslipidemia Increases the Risk of Severe COVID-19: A Systematic Review, Meta-analysis, and Meta-regression. J. Clin. Exp. Hepatol. 2021, 14, 1179551421990675. [CrossRef]

87. Bellia, A.; Andreadi, A.; Giudice, L.; De Taddeo, S.; Maiorino, A.; D’Ippolito, I.; Giorgino, F.M.; Ruotolo, V.; Romano, M.; Magrini, A.; et al. Atherogenic Dyslipidemia on Admission Is Associated with Poorer Outcome in People With and Without Diabetes Hospitalized for COVID-19. Diabetes Care 2021, 44, 2149-2157. [CrossRef]

88. Hu, X.; Chen, D.; Wu, L.; He, G.; Ye, W. Declined serum high density lipoprotein cholesterol is associated with the severity of COVID-19 infection. Clin. Chim. Acta 2020, 510, 105-110. [CrossRef]

89. Zhang, X.-J.; Qin, J.-J.; Cheng, X.; Shen, L.; Zhao, Y.-C.; Yuan, Y.; Lei, F.; Chen, M.-M.; Yang, H.; Bai, L.; et al. In-Hospital Use of Statins Is Associated with a Reduced Risk of Mortality among Individuals with COVID-19. Cell Metab. 2020, 32, 176-187. [CrossRef] 
90. Rosenthal, N.; Cao, Z.; Gundrum, J.; Sianis, J.; Safo, S. Risk Factors Associated with In-Hospital Mortality in a US National Sample of Patients With COVID-19. JAMA Netw. Open 2020, 3, e2029058. [CrossRef]

91. Marić, I.; Oskotsky, T.; Kosti, I.; Le, B.; Wong, R.J.; Shaw, G.M.; Sirota, M.; Stevenson, D.K. Decreased Mortality Rate Among COVID-19 Patients Prescribed Statins: Data from Electronic Health Records in the US. Front. Med. 2021, 8, 639804. [CrossRef]

92. Onorato, D.; Pucci, M.; Carpene, G.; Henry, B.M.; Sanchis-Gomar, F.; Lippi, G. Protective Effects of Statins Administration in European and North American Patients Infected with COVID-19: A Meta-Analysis. Semin. Thromb. Hemost. 2021, 47, 392-399. [CrossRef]

93. Permana, H.; Huang, I.; Purwiga, A.; Kusumawardhani, N.Y.; Sihite, T.A.; Martanto, E.; Wisaksana, R.; Soetedjo, N.N.M. In-hospital use of statins is associated with a reduced risk of mortality in coronavirus-2019 (COVID-19): Systematic review and meta-analysis. Pharmacol. Rep. 2021, 73, 769-780. [CrossRef]

94. Hariyanto, T.I.; Kurniawan, A. Statin therapy did not improve the in-hospital outcome of coronavirus disease 2019 (COVID-19) infection. Diabetes Metab. Syndr. 2020, 14, 1613-1615. [CrossRef]

95. Rosenson, R.S.; Tangney, C.C.; Casey, L.C. Inhibition of proinflammatory cytokine production by pravastatin. Lancet 1999, 353, 983-984. [CrossRef]

96. Schwartz, G.G.; Fayyad, R.; Szarek, M.; DeMicco, D.; Olsson, A.G. Early, intensive statin treatment reduces "hard" cardiovascular outcomes after acute coronary syndrome. Eur. J. Prev. Cardiol. 2017, 24, 1294-1296. [CrossRef]

97. Gunawardene, M.A.; Gessler, N.; Wohlmuth, P.; Heitmann, K.; Anders, P.; Jaquet, K.; Herborn, C.U.; Arnold, D.; Bein, B.; Bergmann, M.W.; et al. Prognostic Impact of Acute Cardiovascular Events in COVID-19 Hospitalized Patients-Results from the CORONA Germany Study. J. Clin. Med. 2021, 10, 3982. [CrossRef]

98. Bonetti, P.O.; Lerman, L.O.; Napoli, C.; Lerman, A. Statin effects beyond lipid lowering-are they clinically relevant? Eur. Heart J. 2003, 24, 225-248. [CrossRef]

99. Dechend, R.; Fiebeler, A.; Park, J.K.; Muller, D.N.; Theuer, J.; Mervaala, E.; Bieringer, M.; Gulba, D.; Dietz, R.; Luft, F.C.; et al. Amelioration of angiotensin II-induced cardiac injury by a 3-hydroxy-3-methylglutaryl coenzyme a reductase inhibitor. Circulation 2001, 104, 576-581. [CrossRef] [PubMed]

100. Castiglione, V.; Chiriacò, M.; Emdin, M.; Taddei, S.; Vergaro, G. Statin therapy in COVID-19 infection. Eur. Heart J. Cardiovasc. Pharmacother. 2020, 6, 258-259. [CrossRef] [PubMed]

101. Spannella, F.; Giulietti, F.; Di Pentima, C.; Sarzani, R. Prevalence and Control of Dyslipidemia in Patients Referred for High Blood Pressure: The Disregarded "Double-Trouble" Lipid Profile in Overweight/Obese. Adv. Ther. 2019, 36, 1426-1437. [CrossRef]

102. Mo, P.; Xing, Y.; Xiao, Y.; Deng, L.; Zhao, Q.; Wang, H.; Xiong, Y.; Cheng, Z.; Gao, S.; Liang, K.; et al. Clinical characteristics of refractory COVID-19 pneumonia in Wuhan, China. Clin. Infect. Dis. 2021, 73, e4208-e4213. [CrossRef]

103. Williamson, E.J.; Walker, A.J.; Bhaskaran, K.; Bacon, S.; Bates, C.; Morton, C.E.; Curtis, H.J.; Mehrkar, A.; Evans, D.; Inglesby, P.; et al. Factors associated with COVID-19-related death using OpenSAFELY. Nature 2020, 584, 430-436. [CrossRef] [PubMed]

104. Grasselli, G.; Zangrillo, A.; Zanella, A.; Antonelli, M.; Cabrini, L.; Castelli, A.; Cereda, D.; Coluccello, A.; Foti, G.; Fumagalli, R.; et al. Baseline Characteristics and Outcomes of 1591 Patients Infected With SARS-CoV-2 Admitted to ICUs of the Lombardy Region, Italy. JAMA 2020, 323, 1574-1581. [CrossRef] [PubMed]

105. Iaccarino, G.; Grassi, G.; Borghi, C.; Carugo, S.; Fallo, F.; Ferri, C.; Giannattasio, C.; Grassi, D.; Letizia, C.; Mancusi, C.; et al. Gender differences in predictors of intensive care units admission among COVID-19 patients: The results of the SARS-RAS study of the Italian Society of Hypertension. PLoS ONE 2020, 15, e0237297. [CrossRef]

106. Rapp, J.L.; Lieberman-Cribbin, W.; Tuminello, S.; Taioli, E. Male Sex, Severe Obesity, Older Age, and Chronic Kidney Disease Are Associated With COVID-19 Severity and Mortality in New York City. Chest 2021, 159, 112-115. [CrossRef]

107. Peckham, H.; de Gruijter, N.M.; Raine, C.; Radziszewska, A.; Ciurtin, C.; Wedderburn, L.R.; Rosser, E.C.; Webb, K.; Deakin, C.T. Male sex identified by global COVID-19 meta-analysis as a risk factor for death and ITU admission. Nat. Commun. 2020, 11, 6317. [CrossRef]

108. White, M.C.; Fleeman, R.; Arnold, A.C. Sex differences in the metabolic effects of the renin-angiotensin system. Biol. Sex Differ. 2019, 10, 31. [CrossRef]

109. Bukowska, A.; Spiller, L.; Wolke, C.; Lendeckel, U.; Weinert, S.; Hoffmann, J.; Bornfleth, P.; Kutschka, I.; Gardemann, A.; Isermann, B.; et al. Protective regulation of the ACE2/ACE gene expression by estrogen in human atrial tissue from elderly men. Exp. Biol. Med. 2017, 242, 1412-1423. [CrossRef] [PubMed]

110. Komukai, K.; Mochizuki, S.; Yoshimura, M. Gender and the renin-angiotensin-aldosterone system. Fundam. Clin. Pharmacol. 2010, 24, 687-698. [CrossRef]

111. Culebras, E.; Hernández, F. ACE2 is on the X chromosome: Could this explain COVID-19 gender differences? Eur. Heart J. 2020, 41, 3095. [CrossRef]

112. Gupte, M.; Thatcher, S.E.; Boustany-Kari, C.M.; Shoemaker, R.; Yiannikouris, F.; Zhang, X.; Karounos, M.; Cassis, L.A. Angiotensin converting enzyme 2 contributes to sex differences in the development of obesity hypertension in C57BL/6 mice. Arterioscler. Thromb. Vasc. Biol. 2012, 32, 1392-1399. [CrossRef] [PubMed]

113. Toering, T.J.; Gant, C.M.; Visser, F.W.; van der Graaf, A.M.; Laverman, G.D.; Danser, A.H.J.; Faas, M.M.; Navis, G.; Lely, A.T. Sex differences in renin-angiotensin-aldosterone system affect extracellular volume in healthy subjects. Am. J. Physiol. Renal Physiol. 2018, 314, F873-F878. [CrossRef] [PubMed] 
114. Ji, H.; de Souza, A.M.A.; Bajaj, B.; Zheng, W.; Wu, X.; Speth, R.C.; Sandberg, K. Sex-Specific Modulation of Blood Pressure and the Renin-Angiotensin System by ACE (Angiotensin-Converting Enzyme) 2. Hypertension 2020, 76, 478-487. [CrossRef]

115. Wu, Z.; McGoogan, J.M. Characteristics of and Important Lessons from the Coronavirus Disease 2019 (COVID-19) Outbreak in China: Summary of a Report of 72314 Cases from the Chinese Center for Disease Control and Prevention. JAMA 2020, 323, 1239-1242. [CrossRef]

116. Palmieri, L.; Palmer, K.; Lo Noce, C.; Meli, P.; Giuliano, M.; Floridia, M.; Tamburo de Bella, M.; Piccioli, A.; Brusaferro, S.; Onder, G. Differences in the clinical characteristics of COVID-19 patients who died in hospital during different phases of the pandemic: National data from Italy. Aging Clin. Exp. Res. 2021, 33, 193-199. [CrossRef] [PubMed]

117. Becerra-Muñoz, V.M.; Núñez-Gil, I.J.; Eid, C.M.; García Aguado, M.; Romero, R.; Huang, J.; Mulet, A.; Ugo, F.; Rametta, F.; Liebetrau, C.; et al. Clinical profile and predictors of in-hospital mortality among older patients hospitalised for COVID-19. Age Ageing 2021, 50, 326-334. [CrossRef]

118. Polidori, M.C.; Sies, H.; Ferrucci, L.; Benzing, T. COVID-19 mortality as a fingerprint of biological age. Ageing Res. Rev. 2021, 67, 101308. [CrossRef]

119. Xie, X.; Chen, J.; Wang, X.; Zhang, F.; Liu, Y. Age- and gender-related difference of ACE2 expression in rat lung. Life Sci. 2006, 78, 2166-2171. [CrossRef] [PubMed]

120. AlGhatrif, M.; Cingolani, O.; Lakatta, E.G. The Dilemma of Coronavirus Disease 2019, Aging, and Cardiovascular Disease: Insights from Cardiovascular Aging Science. JAMA Cardiol. 2020, 5, 747-748. [CrossRef]

121. Spannella, F.; Di Pentima, C.; Giulietti, F.; Buscarini, S.; Ristori, L.; Giordano, P.; Sarzani, R. Prevalence of Subclinical Carotid Atherosclerosis and Role of Cardiovascular Risk Factors in Older Adults: Atherosclerosis and Aging are Not Synonyms. High blood Press. Cardiovasc. Prev. Off. J. Ital. Soc. Hypertens. 2020, 27, 231-238. [CrossRef] [PubMed] 